\title{
Upper Lobectomy with Video-assisted Thoracoscopic Surgery in a Patient with Azygos Lobe, Lung Cancer and Emphysematous Lung
}

\author{
Azigos Lob, Akciğer Kanseri ve Amfizematöz Akciğerin Birlikte Olduğu \\ Hastada Video Yardımlı Torakoskopik Cerrahi ile Üst Lobektomi
}

Tayfun Kermenli', Cebrail Azar ${ }^{2}$

\begin{abstract}
Reports of the presence of non-small cell lung cancer along with Azygos lobe are rare in literature. The patient in the present study was being followed up for COPD and emphysematous lung disease, and an azygos lobe anomaly and non-small cell lung cancer detected in the right upper lobe. The biopsy result with EBUS was reported as squamous-cell cancer. Since no distant metastasis was detected in the staging, performed using PET-CT and Cranial MR, the patient underwent a right upper lobectomy and mediastinal lymph node dissection through "VideoAssisted Thoracoscopic Surgery". As was the case in our patient, the azygos lobe can restrict some thoracic surgical interventions, but this case report showed that in such patients, an upper lobectomy can be performed safely through video-assisted thoracoscopic surgery.
\end{abstract}

Key words: Azygos lobe, lung cancer, emphysematous lung, video-assisted thoracoscopic surgery, upper lobectomy.

\section{Özet}

Azigos lob ile birlikte küçük hücreli dışı akciğer kanserinin varlığı nadiren bildirilmiştir. $\mathrm{KOAH}$ ve amfizematöz akciğer hastalığı nedeniyle takip edilen hastamızda sağ üst lobda azigos lob anomalisi ve küçük hücreli dışı akciğer kanseri saptandı. EBUS ile biyopsi sonucu yassı epitel hücreli kanser olarak rapor edildi. PET-BT ve Kraniyal MR ile yapilan evrelemede uzak metastaz saptanmadığından hastaya video yardımlı torakoskopik cerrahi ile sağ üst lobektomi ve mediastinal lenf nodu diseksiyonu yapıldı. Hastamızda da olduğu gibi Azigos lob, bazı torasik cerrahi girişimler açısından kısıtlamalar oluşturmaktadır, ancak bu olgu raporu, bu hastalarda video yardımlı torakoskopik cerrahi ile üst lobektominin güvenle yapılabilceğini göstermiştir.

Anahtar Sözcükler: Azigoz lobu, akciğer kanseri, amfizematöz akciğer, video yardımlı torakoskopik cerrahi, üst lobektomi.
'Department of Thoracic Surgery, İstanbul Aydın University, İstanbul, Turkey

${ }^{2}$ Department of Chest Diseases, Medicalpark Elazığ Hospital, Elazığ, Turkey
'İstanbul Aydın Üniversitesi, Göğüs Cerrahisi Bölümü, İstanbul ${ }^{2}$ Medicalpark Elazığ Hastanesi, Göğüs Hastalıkları Kliniği, Elazığ

Submitted (Başvuru tarihi): 04.1 1.2020 Accepted (Kabul tarihi): 17.12.2020

Correspondence (iletişim): Tayfun Kermenli, Department of Thoracic Surgery, İstanbul Aydın University, İstanbul, Turkey

e-mail: tayfunkermenli@gmail.com 
The azygos lobe is a most common congenital variation of the lungs, and it is seen in $0.1-8 \%$ of the population $(1,2)$. As the azygos vein passes in front of the lung in the intrauterine period, the right upper lobe apical or posterior segment remains behind this vein. Azygos lobe anomalies are generally asymptomatic and require no treatment. There are case reports of lung surgery performed on patients with azygos lobe in the literature $(2,3)$, however, an association of azygos lobe and non-small cell lung cancer has rarely been reported. Lung resection in these patients has been associated with some difficulties when conducted through video-assisted thoracoscopic surgery (VATS) $(3,4)$. In this case report, we present a patient who underwent an upper lobectomy with VATS due to squamous cell lung cancer in the upper lobe of the right lung in the presence of an azygos lobe.

\section{CASE}

A bilateral chest radiograph of a 55-year-old male patient being followed up due to COPD and emphysematous lung disease revealed a suspicious area in the hilar region of the right upper lobe, along with an azygos lobe. The patient was further investigated with a thorax computed tomography $(\mathrm{CT})$, revealing a mass lesion in the area adjacent to the upper lobe bronchus with a 30×35 $\mathrm{mm}$ spicular contour (Figure 1a, b, and c). Widespread heterogeneous emphysematous areas were also noted in both lung upper lobes. The patient was diagnosed with squamous cell carcinoma upon an endobronchial ultrasonographic biopsy (EBUS).

For distant organ metastasis screening and tumor staging, positron emission tomography (PET-CT) and cranial magnetic resonance (MR) were performed. The PET-CT revealed a $30 \times 39 \mathrm{~mm}$-sized spicular contoured lesion in the right lung hilar region, and the SUVmax value was measured as 13.8 (Figure 1d). Since there were no additional findings other than the tumor area, it was decided to perform an upper lobectomy. In a respiratory function test carried out to evaluate the patient's preoperative respiratory capacity, the reported forced expiratory volume (FEV1) was $2180 \mathrm{ml}$ and $72 \%$ at 1 second, and $\mathrm{FEV} 1 / \mathrm{FVC}$ ratio was $68 \%$. In a 6 min walking test, the patient recorded a walking distance of around $460 \mathrm{~m}$. As a result of these tests, an upper lobectomy was planned for the patient with VATS. The localization of the mass in the upper lobe allowed us the opportunity to carry out lung volume reduction surgery together with cancer surgery.

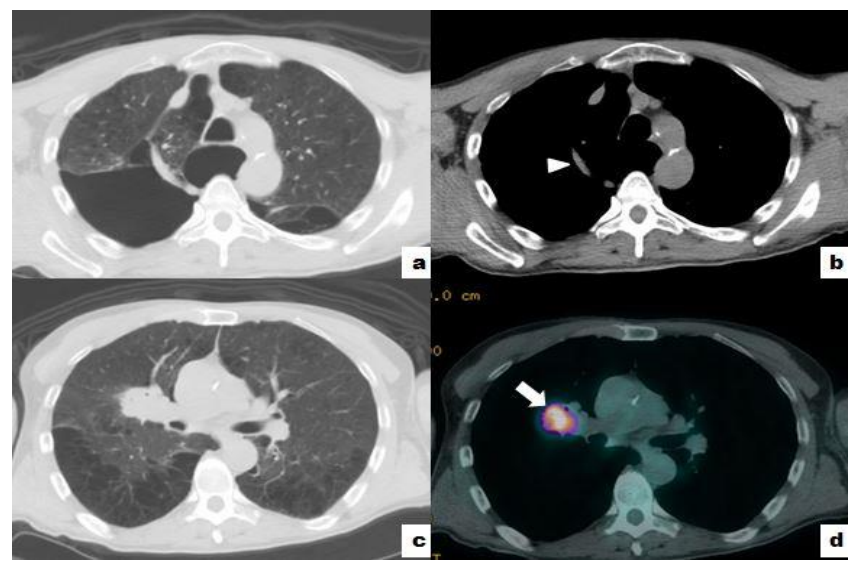

Figure 1a, b, c and d: CT images of the azygos lobe and upper lobe emphysema in a parenchyma window (a), the azygos vein in mediastinal window (arrowhead) (b), CT images of the right lung upper lobe hilar mass (c), PET-CT images of the mass (arrow) (d)

The patient underwent a right upper lobe resection and mediastinal lymph node dissection with VATS. Right 7th intercostal space (ics) anterior axillary line and 8 ics posterior axillary line port entry incisions, and a 4 ics anterior axillary line $3 \mathrm{~cm}$ working incision was opened. The azygos lobe was exposed during the operation, the pleura above the azygos vein was dissected and the lobe was released from the posterior of the azygos vein (Figure 2). The patient underwent a right upper lobectomy and mediastinal lymph node dissection, and a 28 French drain was placed in the thorax after the operation.

Prolonged air leakage developed in the postoperative follow-up of the patient, and so the thorax drain was removed on the 12th postoperative day, and the patient was discharged on the 13th day. As a pathology diagnosis, tumor diameter: $25 \times 20 \mathrm{~mm}$, tumor metastasis was present in the hilar lymph node, and no tumor was detected in the mediastinal lymph node stations numbered $2,4,7,8$ or 9 . Based on these findings, adjuvant chemotherapy was planned for the patient by the oncological tumor council. No problems were encountered at the 6thmonth follow-up of the patient.

\section{DISCUSSION}

The azygos lobe is the best known and most common anatomical variant of the lung, the etiology of which has been linked to a defect in the azygos vein migration during embryonic development. The azygos vein is located in the anterior of the upper lobe of the right lung, thereby forming an accessory fissure known as the "azygos fissure", which can be vertical or oblique. The lung tissue located in the apical and posterior part of this fissure is known as the "azygos lobe." PA chest radiography is 
generally sufficient for the diagnosis of this anomaly, although in cases such as ours, thorax CT and PET-CT may be used as additional diagnostic methods. The use of lung perfusions scintigraphy is also recommended in the case of bullous lungs (1).

Along with the azygos lobe, bullous lung, pneumothorax and lung cancer have also been reported. In terms of standard cancer surgery, an upper lobectomy is recommended in these patients. Sezer et al. (2) reported that an azygos segmentectomy may also be performed in patients with limited respiratory function. We opted for an upper lobectomy in this patient because the tumor was centrally located. The patient's upper lobe and azygos lobe were emphysematous in nature, allowing the performance of tumor surgery and lung volume reduction surgery together.

Although the azygos lobe is known to cause some difficulties during thoracic surgical procedures, cases with lung resection through VATS or robotic assisted thoracoscopic surgery (RATS) have been reported in literature (3-5). Papiashvili et al. (6) successfully performed thoracoscopic surgery in a case with a synchronous bilateral lung tumor and an azygos lobe. Lung adhesions were also present in our patient, so during resection of the upper lobe the azygos vein was gently dissected, and the primary mobilization of the accessory lobe was provided. An anatomical lung resection was performed, along with a standard mediastinal lymph node dissection. We attributed the development of prolonged air leakage in our patient mainly to the whole lung tissue being emphysematous.

An azygos lobe is detected incidentally in many patients. Due to the anatomical location of this variation, care should be taken during interventions such as upper lobectomy or sympathectomy performed in this region. However, our case report, and a limited number of other articles in literature, has reported thoracic surgeries being safely performed with VATS or RATS in these patients.

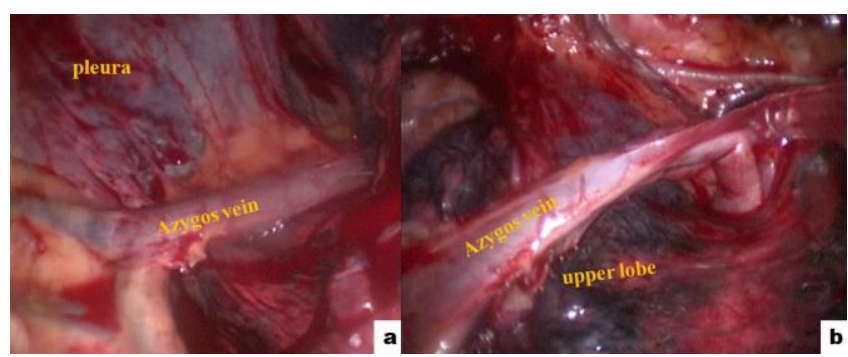

Figure $2 a$ and $b$ : Pre-operative images of the pleura above the azygos vein (a), right upper lobe and azygos vein (b)

\section{CONFLICTS OF INTEREST}

None declared.

\section{AUTHOR CONTRIBUTIONS}

Concept - T.K., C.A.; Planning and Design - T.K., C.A.; Supervision - T.K., C.A.; Funding - T.K., C.A.; Materials T.K.; Data Collection and/or Processing - C.A.; Analysis and/or Interpretation - T.K.; Literature Review - C.A.; Writing - T.K., C.A.; Critical Review - T.K.

\section{YAZAR KATKILARI}

Fikir - T.K., C.A.; Tasarım ve Dizayn - T.K., C.A.; Denetleme - T.K., C.A.; Kaynaklar - T.K., C.A.; Malzemeler T.K.; Veri Toplama ve/veya İşleme - C.A.; Analiz ve/veya Yorum - T.K.; Literatür Taraması - C.A.; Yazıyı Yazan T.K., C.A.; Eleştirel İnceleme - T.K.

\section{REFERENCES}

1. Gürkök S, Gözübüyük A, Yücel $O$, Çaylak H, Dakak M. A case of bullous azygos lobe, Turk Gogus Kalp Damar Cerrahisi Derg. 2007; 15:168-9.

2. Sezer HF, Abdullayev G, Avcı A, Özbay S, Topçu S. Segmentectomy for primer lung cancer, which arise from azygos lobe: azygos lobectomy. Tuberk Toraks. 2019; 67:231-3. [CrossRef]

3. Fukuhara S, Montgomery M, Reyes A. Robot-assisted azygos lobectomy for adenocarcinoma arising in an azygos lobe. Interact Cardiovasc Thorac Surg 2013; 16:715-7. [CrossRef]

4. Samancilar $O$, Akçam Ti, Kaya SO, Sevinc S, Akcay O, Ceylan KC. Video-assisted thoracoscopic surgery (VATS) right upper lobectomy for non-small-cell lung cancer with an azygos lobe. Kardiochir Torakochirurgia Pol 2016; 13:373-4. [CrossRef]

5. Arai H, Inui K, Kano K, Nishii T, Kaneko T, Mano H, et al. Lung cancer associated with an azygos lobe successfully treated with video-assisted thoracoscopic surgery. Asian J Endosc Surg 2012; 5:96-9. [CrossRef]

6. Papiashvili M, Hayat H, Schreiber L, Priel IE. Thoracoscopic azygos vein lobe resection in a patient with synchronous right and left lung cancer. Isr Med Assoc J 2015; 17:387-8. 